\title{
Usage of Information and Communication Technologies in Maritime Educational Institutions
}

\author{
Nina Slyusarenko 1 [0000-0002-9215-5936], Olena Zadorozhnya ${ }^{2}$ * [0000-0003-4514-8810] \\ ${ }^{1}$ Kherson State University, Kherson, Ukraine \\ ${ }^{2}$ Communal Higher Educational Establishment «Kherson Academy of Continuing Education» of Kherson Regional \\ Council, Kherson, Ukraine \\ *lesjazadorozhnjaja@gmail.com
}

\begin{abstract}
Rampant development of information and communication technologies had considerable impact on all the spheres of human life and education in particular. Nowadays educational sector mainstream e-learning as it has numerous advantages. A number of issues including teachers' low awareness in the area of information and communication technologies hinder mass implementation of e-learning. In maritime educational institutions on the south of Ukraine vast majority of teachers use information and communication technologies in educational process yet they face difficulties and have a need to be trained on how to create distant courses and conduct teaching on-line. Raising awareness of teaching staff in these educational institutions in contemporary information and communication technologies and possibilities of their application in the educational process may be done via "training while working" or in postgraduate education while mastering special course "Moodle platform as one of the means of information and communication technologies for organizing electronic learning (eLearning) in maritime educational institutions". Implementation of the special course allows tackling the issue of educational process organization using distant platform Moodle, which in turn will have positive impact on students' learning efficiency.
\end{abstract}

Keywords: information and communication technologies, maritime educational institutions, teachers, special course, Moodle platform.

\section{INTRODUCTION}

The development of information and communication technologies (ICT) as well as global information infrastructure caused relevant amendments in all the spheres of human life. That is why nowadays we started eliminating the usage of traditional methods yet applied the above mentioned technologies instead. They help to fulfill all the set tasks [1] first and foremost in the sphere of education.

As proved by teaching practice, in three hours a person can reproduce only $70 \%$ of teaching information which has been heard, in three days only $10 \%$ of information are left. Teaching information which has been seen will be reproduced in $85 \%$ in three hours, in three days only $20 \%$ of information remain memorized. Information which has been heard and seen can be memorized much better (in three hours - 85\% of information, in three days - 65\%). Hence, it is possible to advance the efficiency of teaching via the application of ICT [2]. They help students to acquire process and transfer received information more efficiently.

Network educational environment, digitizing of educational resources and variability of education are typical for the age of so-called "global information system development". Meanwhile e-learning rapidly assumes extreme importance for both teachers and students [3].

E-learning is often treated like the synonym to the concept of "electronic learning" and a number of other related and widely used ideas (distant teaching, mobile learning, virtual learning, computer-based teaching, and multimedia teaching).

Recently many countries not just use the term "elearning" but also have rather successful experience of organizing the whole educational process basing on the concept of e-learning. It can be explained with the fact that e-learning has numerous advantages (availability anywhere anytime, unlimited possibility of on-line 
communication for all the participants of teaching process, simultaneous usage of multiple sources of information, etc.) [3]. Yet nowadays there is a number of issues in Ukraine which interfere wide implementation of e-learning in general and ICT in particular. They include low awareness of some teacher in terms of these technologies and their ignorant usage. However, usage of information and communication technologies in educational institutions is dictate of the times.

Nevertheless it should be taken into consideration that any information technologies are used only in the cases when it helps students to master abstract course content faster and that excessive usage of information technologies can have negative impact on a person's conceptual thinking ability. Namely information technologies simplify studying of complex subjects yet the educt is not always desirable [2]. Taking into consideration all the above mentioned, it is appropriate to concern with the question of teaching staff training (in maritime educational institutions in particular) for wellconsidered use of ICT while teaching various subjects.

\section{RESEARCH METHODOLOGY}

The methodological basis includes predominant theories, pedagogical ideas (about digital didactics in particular) and principles of scientificity, integrated approach, availability and integrity which explain key aspects of the problem under consideration, and also the set of general-theoretical and empirical methods of research (analysis of learned treatise and pedagogical experience in terms of using ICT in maritime educational institutions, their taxonomy, questionnaire survey for teaching staff in order to figure out the problem state and introspection after the solution, consolidation of research results, their description and graphic display, design and organization of work aimed at raising teachers' awareness of modern ICT).

The research embraces 156 members of academic teaching staff from maritime educational institutions on the south of Ukraine regarding their usage of ICT in training of future specialists. Obtained results proved the necessity of conducting focused awareness-building work among teaching staff, induced to development and implementation of corresponding special course.

\section{RESEARCH RESULTS}

The analysis of questionnaire survey results showed that in maritime educational institutions the majority of academic teaching staff members use ICT in teaching process $(81,0 \%)$. The rest of the respondents either apply these technologies partially $(14,0 \%)$, or don't use them at all $(5,0 \%)$.

The leaders in using ICT are teachers from cycle committee of information technologies, engineering and computer graphics $(31,0 \%)$ and subject committee of English language $(29,4 \%)$. Other teachers use the above mentioned technologies much more rarely. Of these there are teachers of socio-humanitarian subjects $(11,0 \%)$, physical and mathematical science $(9,6 \%)$, Ukrainian studies, professional subjects, ecology, health and safety and professional safety $(5,7 \%)$, physical training $(1,9 \%)$.

Most participants of questionnaire survey prefer maintenance of professional ties and communication via e-mail $(34,6 \%)$. Some respondents use social media $(21,0 \%)$, pedagogical online communities $(21,0 \%)$, audio- and video chats (Skype, Viber, Zoom) $(14,0 \%)$ for the same purpose. Only a few respondents use Wiki $(3,9 \%)$, blogs, sites, platforms, cloud technologies $(3,0 \%)$ and forums $(2,5 \%)$.

In teachers' opinion, it is the most efficient to use ICT while revision of new knowledge $(40,4 \%)$, presentation of a new material $(28,2 \%)$ and testing $(28,2 \%)$. Meanwhile the usage of the above mentioned technologies proved to be almost inefficient in doing home tasks and individual works $(3,2 \%)$.

Respondents mentioned as the most popular and efficient the following training recourses: platforms for electronic learning $(39,7 \%$ and $37,2 \%$ respectively); multimedia presentations $(35,3 \%$ and $44,9 \%$ respectively); websites (25,0\% and $17,9 \%$ respectively).

While training future maritime specialists academic staff use platform for organizing distant teaching "Moodle" the most $(69,9 \%)$, as it has substantial advantages: free access, possibility to study and teach asynchronously, possibility to conduct testing online, etc. Platforms like "Google Classroom" (14,7\%) and "Prometheus" (9,0\%) are used much more rarely, and «Edmodo» is used by only 3,2\%. Unfortunately there are teachers who don't use any platforms for organizing the teaching process in their professional activity $(3,2 \%)$.

As to whether teachers use any software for videoconferencing with students (Skype, Viber, Zoom, etc.), $69,9 \%$ of questionnaire survey participants answered "yes" and explained that this way the communicate on-line (creating groups of several students in particular), send files of various sizes, pictures and so on. Software for videoconferencing is used partially by $25,6 \%$ of respondents, and only $4,5 \%$ don't use any software of this kind in their work with students.

Academic staff consider the usage of ICT in teaching process has positive impact on the quality of training of maritime specialists as students have unlimited access to learning materials any time comfortable for them (these answers were given by $27,0 \%$ of respondents); in the same time the technologies increase opportunities for efficient organization of individual work $(24,0 \%)$, creation of flexible schedule for studying a course $(12,0 \%)$; students develop skills of self-organization $(18,0 \%)$, hence their performance level increases $(10,0 \%)$, they receive positive emotions and motivation 
and efforts in the area of knowledge acquiring increase $(9,0 \%)$.

However they have expressed raised concerns about the usage of excessive number of ICT which, in their opinion, can have negative impact like impairment in ability to work with texts and printed editions $(35,0 \%)$; low level of knowledge on some particular topics $(20,0 \%)$; feeling unwell $(20,0 \%)$; less time for "real-life communication" $(15,0 \%)$. Other negative consequences, mentioned by teachers $(10,0 \%)$, include students distraction, occurrence of irritability and aggression; impairment in ability of logical thinking and doing tasks.

All the respondents agree that the efficiency of ICT usage in maritime educational institutions depends on various factors, first and foremost in the ability to use modern equipment and corresponding technologies.

Yet lack of time $(33,0 \%)$ and necessary learning and teaching support material $(21,0 \%)$, lack of computers $(12,0 \%)$, issues with internet connection in maritime educational institutions where they work $(10,0 \%)$ hinder teachers to learn how to use this equipment and ICT. Among other things $15,0 \%$ of respondents mentioned ated software and lack of knowledge and skills of work with modern ICT they have.

The conducted research proved the necessity of raising awareness about modern ICT and the possibilities of their efficient application in teaching process among academic staff of maritime educational institutions.

\section{RESULTS AND DISCUSSION}

In Ukraine like in other countries of the world teachers are the agents of any changes in education. That is why it is extremely important to supply them with the most advanced methods, application of ICT in particular. It will promote development of teacher's digital competencies and the ability of lifelong learning. All the above mentioned is of extreme importance as only qualified teacher who aims for and is capable of constant self-improvement can develop the same features in young generation [4].

There's no doubt that any person who aims for studying can choose any educational trajectory from the proposed options of various way to obtain certain educational services. Obviously it refers to teachers perhaps the most as they study lifelong via self-education or centralized, organized and focused upskilling, which in turn expands their personalized educational system including digital one.

One of the modern and comparatively efficient ways of creating personalized digital educational system is the application of ICT, which help the one who studies to get necessary information independently.

ICT are defined as a set of methods, means and techniques which can be used for collection, arrangement, storage, processing, transferring and presentation of various kinds of information (messages and data) [5]. There's more detailed definition of this term where ICT is treated as a set of methods, production processes, hardware and software, integrated for collection, processing, storage, distribution, display and usage of information depending on the interests of users [6].

ICT application gives educational institutions the possibility to raise competency and disrupt their teaching and learning environment. Consequently their development and implementation have become prevalent direction of numerous investments [7].

It needs to be acknowledged that nowadays ICT are successfully applied in higher educational institutions during lessons, individual work, practical training, tests, etc. Internet is widely used during seminar-workshops, seminar-trainings, webinars, virtual lectures, panel discussions, just to name a few. Internet comes in handy for teachers while creating presentations, searching for necessary video clips and films, communication with students and colleagues (for example via creation of virtual subject communities, virtual environment).

Experience proves that teaching of academic staff in maritime educational institutions on how to work with these and other services and platforms can be conducted via so-called "studying at work" or postgraduate studies while mastering corresponding special course.

Meanwhile it should be taken into consideration that a program of a special course can include lessons with various levels of cooperation which suppose usage of active innovative forms of organization of studies, application of interactive methods and focused on the usage of professionally oriented information technologies in teaching process [8]. Meaningful modules are built as a system of teaching elements (chapters, topics, etc.) composed in accordance with a certain object of professional activity [9]. And it should be remembered that new technologies are implemented all the time and are rapidly becoming obsolete as soon as they appear [10]

Taking into consideration all the above mentioned and teachers' requests "to study how to create distant courses and conduct on-line teaching" especially during COVID-19 pandemic which were expressed during incoming questionnaire survey (its results are given above) the special course "Moodle platform as one of the means of ICT for organizing of electronic learning (eLearning) in maritime educational institutions" was created (table 1). The choice of this agenda is connected with the intensification of using Moodle platform in maritime educational institutions on the south of Ukraine.

The aim of the course is professional development of academic staff in maritime educational institutions and 
organization of educational process with the implementation of ICT, namely Moodle platform.

The target audience of the course is teachers of various qualification grades and specialities who wish to apply information technologies in the educational process in order to increase motivation of cadets, quality of education and own level of informational digital competency.

Table 1. Syllabus of the course "Moodle platform as one of the means of ICT for organizing of electronic learning (eLearning) in maritime educational institutions"

\begin{tabular}{|c|c|c|c|c|c|}
\hline \multirow[b]{2}{*}{ № } & \multirow[b]{2}{*}{ Training subject } & \multirow{2}{*}{$\begin{array}{l}\text { Total } \\
\text { number } \\
\text { of hours }\end{array}$} & \multicolumn{3}{|c|}{ Of which } \\
\hline & & & Lectures & $\begin{array}{l}\text { Practical } \\
\text { lessons }\end{array}$ & $\begin{array}{l}\text { Individual } \\
\text { work }\end{array}$ \\
\hline \multicolumn{6}{|c|}{ Module 1. Theoretical basics of ICT usage in maritime educational institutions } \\
\hline 1 & $\begin{array}{l}\text { ICT: essence, role and ways of application in educational } \\
\text { process }\end{array}$ & 2 & 2 & & \\
\hline 2 & $\begin{array}{l}\text { Organization of distant and mixed teaching processes in } \\
\text { maritime educational institutions }\end{array}$ & 4 & 2 & & 2 \\
\hline 3 & $\begin{array}{l}\text { Moodle as a platform for organization of electronic learning } \\
\text { (eLearning) }\end{array}$ & 6 & 4 & & 2 \\
\hline \multicolumn{6}{|c|}{ Module 2. Practical usage of ICT in maritime educational institutions } \\
\hline 4 & $\begin{array}{l}\text { Creation and completion of personal profile. Usage of main } \\
\text { Moodle elements. }\end{array}$ & 2 & & 2 & \\
\hline 5 & Usage of SCORM package and LearningApps platform & 2 & & 2 & \\
\hline 6 & Creation and setting of grade book & 4 & & 2 & 2 \\
\hline 7 & Usage of infographics in Moodle platform & 4 & 2 & 2 & \\
\hline 8 & $\begin{array}{l}\text { Organization of lectures and practical lessons in Zoom, } \\
\text { Google Meet, Microsoft Teams }\end{array}$ & 4 & 2 & 2 & \\
\hline \multicolumn{6}{|c|}{ Module 3. Exploratory-analytical } \\
\hline 9 & Creation of own course & 2 & & 2 & \\
\hline & Total: & 30 & 12 & 12 & 6 \\
\hline
\end{tabular}

Course task: to familiarize with the essence, role and application of ICT in educational process in maritime educational institutions; to provide theoretical knowledge and form practical skills for using Moodle platform in organization of educational process; to improve skills of on-line teaching using additional ICT; to train teachers on how to create and practically apply in professional activity own course on Moodle platform; to raise teachers' level of informational digital competency.

As a result of the course an applicant: receives knowledge, skills and abilities in organization of communication-oriented informational digital environment, which is crucial for successful professional performance in maritime educational institutions; knows how to use contemporary universal informational digital technologies and work on Moodle platform; raises the level of informational digital competency.

The program of the special course is designed for 30 hours of which 12 are lectures, 12 are practical lessons, 6 are individual work. The distribution of hours is not permanent and can be changed depending on the needs.

The program consists of three interconnected modules: theoretical basics of ICT usage; practical usage of ICT in maritime educational institutions; exploratoryanalytical module (creation of own course). During the implementation of the program various forms of cooperation, training and interactive forms of lesson organization have been used.

A significant quantity of time is given for the practical application of gained knowledge as for the work with Moodle platform: creation and completion of personal profile, creation and setting of grade book, creation of own course and filling with content, usage of SCORM package and service for creation of interactive tasks on different complexity levels (LearningApps).

While acquisition of the first module the following questions are considered: the essence of ICT, their role and directions, peculiarities of usage in educational process; the essence of distant and mixed learning; the most popular platform for distant learning - Moodle. The second module is aimed at the modeling and creation of own course on Moodle platform and also at the practical implementation of conducting online-lessons with the help of other platforms, namely Zoom, Google Meet, Microsoft Teams. Exploratory analytical module includes final testing and detailed review of own created course.

The conducted research showed significant interest of teachers in the offered course Проведене дослідження показало значну зацікавленість викладачів 
запропонованим спеціальним курсом "Moodle platform as one of the means of ICT for organizing of electronic learning (eLearning) in maritime educational institutions", as after the completion of the course teachers created own courses on the subjects they teach. The sample of the course "Specialized maritime English" are given on Fifure 1.

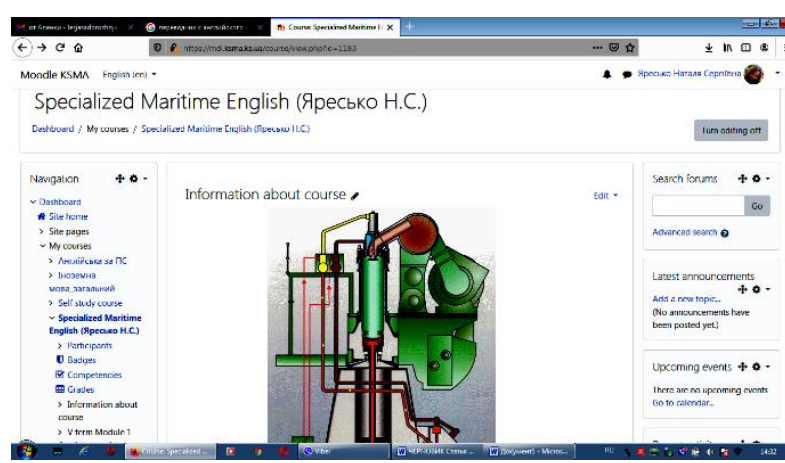

Figure 1 Course of the subject "Specialized maritime English"

Teachers liked to create and work with "Grade book" where all the information about cadets, registered for the course, types of tasks they did and marks they received is displayed.

Besides the above mentioned teachers created a set of test task for each course which were oriented on the fixation of studied material.

Final testing showed considerably high level of acquisition of knowledge among teachers, their practical experience became a solid base for further work in the system of distant and mixed teaching.

Improving own courses teachers have added interactive elements there. One of the teachers in Kherson State Maritime Academy has developed special simulator for studying the topic "Pendulums" within studying subject "Physics".

After the course completion self-analysis in the form of questionnaire has been conducted. Vast majority of respondents $(85,3 \%)$ answered they liked to work on Moodle platform, mentioning that it provides plenty of opportunities for better receiving and acquisition of knowledge. $69,9 \%$ are sure that the usage of the platform increased their confidence as IT users. Also they emphasized the comfort of work, as it is possible to work in Moodle at home (to fill with content, to control and assess knowledge).

Almost all the respondents $(94,9 \%)$ stated that they had already started to use Moodle platform in their professional activity, of which: 79,7\% - constantly; $20,3 \%$ - occasionally. The rest respondents $(5,1 \%)$ do not use the platform as they still prefer live communication.

\section{CONCLUSIONS}

The conducted analysis of scientific information sources on the the problem under consideration allowed to detect that contemporary information society requires the usage of informational and communication technologies in all spheres of life, including educational sphere. Questionnaire survey of academic staff in maritime educational institutions showed that the majority of teachers use these technologies yet they face certain difficulties. In order to raise their awareness in modern informational and communication technologies and their usage in educational process the special course "Moodle platform as one of the means of ICT for organizing of electronic learning (eLearning) in maritime educational institutions" was created; its implementation solves the existing issue and increases quality of teaching.

\section{REFERENCES}

[1] Putu Wulan Wahyu Sandhiani, I. Putu Agus Eka Pratama and I. Made Sukarsa (2019), "The Improvement of IT Processes at Office X in one of the Cities in Indonesia", International Journal of Information Engineering and Electronic Business, vol. 11 , no. 6 pp. $1-8$.

[2] Li, W. Zhou, R. Deng, P. Fang, Q. and Zhang, P. (2012), "Construction of Case Teaching Model for Management Specialty Supported by Information Technology", Int. J. Education and Management Engineering, vol. 2, no. 9, pp. 44-48.

[3] Yu, L. (2011), "Work-Integrated Teaching Mode Based on an E-learning Platform", Int. J. Education and Management Engineering, vol. 1, no. 4, pp. 34-40. DOI: 10.5815/ijeme.2011.04.06

[4] Zubko, A. M. Zhorova, I.Y. Kuzmenko, V.V. Slyusarenko, N. V. and Kokhanovska, O.V. (2020), "Information and communication technologies as a factor in the development of professionalism of teachers in the system of postgraduate education", Informatsiini tekhnolohii i zasoby navchannia, vol. 77, no. 3, pp. 262-281.

[5] Zhaldak, M. I. (1991), "Problems of informatization of the educational process at school and university", Suchasna informatsiina tekhnolohiia v navchalnomu protsesi, pp. 3-17.

[6] Krupskyi, Ya. V. and Mykhalevych, V. M. (2010), Tlumachnyi slovnyk z informatsiinopedahohichnykh tekhnolohii: slovnyk [Explanatory dictionary of information and pedagogical technologies: a dictionary], VNTU, Vinnytsia, Ukraine.

[7] Qi, B., Liu, L. and Wang, Ch. (2009), "E-learning Tools to Improve Students’ Learning Experience: a 
case study", Int. J. Modern Education and Computer Science, vol. 1, no. 1, pp. 1-9.

[8] Osypova, N. Kokhanovska, O. Yuzbasheva, G. and Kravtsov, H. (2020), "Augmented and Virtual Reality Technologies in Teacher Retraining", The 16th Int. Conf. on ICT in Education, Research and Industrial Applications. Integration, Harmonization and Knowledge Transfer (ICTERI2020), Kharkiv, Ukraine, vol. 2732, pp. 1203-1216.

[9] Makarenko, L. Slabko, V. Kononenko, A. Musorina, M. and Smyrnova, I. (2020), "Pedagogical aspects of ensuring the efficiency of education of Applicants of higher education institutions of Ukraine in the process of research of technical disciplines", Journal of Critical Reviews, vol. 7, no. 13, pp. 116-118.

[10] Bogdanović, M. (2012), "Growing Importance of Distance Education", Int. J. Modern Education and Computer Science, vol. 4, no. 3, pp. 35-41. 